\title{
A critical interpretive synthesis of the roles of midwives in health systems
}

\author{
Cristina A. Mattison ${ }^{1 *}\left(\mathbb{D}\right.$, John N. Lavis ${ }^{2}$, Michael G. Wilson², Eileen K. Hutton ${ }^{1}$ and Michelle L. Dion ${ }^{3}$
}

\begin{abstract}
Background: Midwives' roles in sexual and reproductive health and rights continues to evolve. Understanding the profession's role and how midwives can be integrated into health systems is essential in creating evidenceinformed policies. Our objective was to develop a theoretical framework of how political system factors and health systems arrangements influence the roles of midwives within the health system.

Methods: A critical interpretive synthesis was used to develop the theoretical framework. A range of electronic bibliographic databases (CINAHL, EMBASE, Global Health database, HealthSTAR, Health Systems Evidence, MEDLINE and Web of Science) was searched through to 14 May 2020 as were policy and health systems-related and midwifery organisation websites. A coding structure was created to guide the data extraction.

Results: A total of 4533 unique documents were retrieved through electronic searches, of which 4132 were excluded using explicit criteria, leaving 401 potentially relevant records, in addition to the 29 records that were purposively sampled through grey literature. A total of 100 documents were included in the critical interpretive synthesis. The resulting theoretical framework identified the range of political and health system components that can work together to facilitate the integration of midwifery into health systems or act as barriers that restrict the roles of the profession.

Conclusions: Any changes to the roles of midwives in health systems need to take into account the political system where decisions about their integration will be made as well as the nature of the health system in which they are being integrated. The theoretical framework, which can be thought of as a heuristic, identifies the core contextual factors that governments can use to best leverage their position when working to improve sexual and reproductive health and rights.
\end{abstract}

Keywords: Midwifery, Political systems, Health systems, Critical interpretive synthesis, Sexual and reproductive health and rights

\section{Introduction}

Midwives' roles in sexual and reproductive health and rights (SRHR) continue to evolve and an understanding of the profession's role in health systems is essential in creating evidence-informed policies. Countries across all income levels face challenges with providing high-quality SRHR and achieving effective coverage [1]. National or sub-national SRHR policies often do not include the

\footnotetext{
*Correspondence: mattisc@mcmaster.ca

${ }^{1}$ Department of Obstetrics and Gynecology, McMaster Midwifery Research Centre, 1280 Main St. West, HSC-4H26, Hamilton, ON L8S 4K1, Canada

Full list of author information is available at the end of the article
}

midwifery workforce or account for the professions' role in the provision of high-quality care [1]. The lack of conceptual clarity regarding the drivers of midwives' roles within health systems, ranging from their regulation and scope of practice to their involvement in care, has resulted in significant variability both within and across countries on how the profession is integrated into health systems.

Research on midwifery care has demonstrated that the profession delivers high-quality SRHR services [1-3]. Care provided by midwives who are trained, licensed and regulated according to international standards is 
associated with improved health outcomes [3-7]. While midwifery care is associated with positive outcomes, it is an area that is under-researched [8]. This is particularly true in relation to how political and health system factors influence the profession's role in health systems. As such, the roles of midwives in health systems are not clearly understood, which continues to challenge the profession's ability to work effectively in collaborative and interprofessional settings.

Midwifery research is often dichotomised by the development status of the jurisdiction of focus - high-income countries (HICs) compared to low- and middle-income countries (LMICs). In HICs in general, midwives' roles are focused on primary care to low-risk pregnant people through pregnancy, labour and a limited post-partum period [9]. In comparison, in LMICs, midwives' scope of practice can be broader and extends to many aspects of SRHR [10-13]. International organisations (e.g. WHO, United Nations Population Fund and the International Confederation of Midwives) support an expanded approach to midwifery roles to include provision of a range of SRHR services (e.g. health counselling and education, prevention of mother-to-child HIV transmission, prevention and treatment of sexually transmitted infections, and provision of safe abortion where legal) [4, 14].

Arguably one of the most crucial components of a health system is its health workforce, as highlighted by WHO's framework of 'building blocks' to support health systems strengthening (service delivery, health workforce, health information systems, access to essential medicines, financing and governance) [15]. While midwifery is recognised as key to SRHR, there is a global shortage of the midwifery workforce [2, 4]. Midwives who are educated and regulated according to international standards can provide $87 \%$ of a population's essential SRHR, yet only $36 \%$ of the midwifery workforce is made up of such fully trained midwives, with a range of other health workers also delivering midwifery services [4]. The latter has been made possible by the range of roles that non-midwife health workers play in providing midwifery services $[4,16]$.

The lack of understanding of the roles of midwifery in health systems has led to significant disparities within and across countries. A better understanding of the roles of midwives within the health system is desirable as they are a key component in the delivery of safe and effective SRHR and could possibly improve the cost-effectiveness of the delivery of these services [17-19]. There is growing recognition that, to strengthen health systems, decisions must be based on the best available research evidence [20-23]. Using the available research evidence to understand the roles of midwives across health systems, as well as the political and health system drivers, will yield important insights with the aim of adding to the evidence base that policy-makers can draw from.
The present study asks - across health systems, what are the factors that influence the roles of midwives within the health system? We present a theoretical framework to explain how political and health system factors influence the roles of midwives within the health system. It defines the political system as consisting of three main components, namely institutions, interests and ideas [24]. 'Health system arrangements' are made up of governance, financial and delivery arrangements, and implementation strategies [25]. Given the lack of theoretical development in the area, this paper, through a critical interpretive synthesis of the available literature, identifies the factors that act as barriers or facilitators to the roles of midwives.

\section{Methods \\ Design}

A critical interpretive synthesis was used to develop the theoretical framework, which is an inductive approach to literature analysis. The approach uses conventional systematic review processes while incorporating qualitative inquiries to examine both the empirical and nonempirical literature [22]. Critical interpretive syntheses are best suited to developing theoretical frameworks that draw on a wide range of relevant sources and are particularly useful when there is a diverse body of literature that is not clearly defined, as is the case with literature related to the roles of midwives in health systems. Conventional systematic reviews have well formulated research questions at the outset, while a critical interpretive synthesis employs a compass question, which is highly iterative and responsive to the findings generated in the review process [26].

\section{Literature search}

The selection of the literature was carried out in phases (Fig. 1). The first phase consisted of a systematic search of electronic bibliographic databases. The searches were executed in consultation with a librarian, who provided guidance on developing keywords (along with Boolean operators) and MeSH (Medical Subject Heading), refining the search strategy, identifying additional databases and executing the searches. We searched the following electronic databases through to 14 May 2020: CINAHL, EMBASE, Global Health database, HealthSTAR, Health Systems Evidence, MEDLINE and Web of Science. The search strategy was first developed in the MEDLINE database, using keywords and MeSH. Similar search strings were used across databases, with minor adjustments made to ensure search optimisation. The searches in MEDLINE included midwi* AND (roles OR scope), midwi* AND delivery of health care $(\mathrm{MeSH})$, midwi* AND patient satisfaction $(\mathrm{MeSH})$, midwi* AND quality 


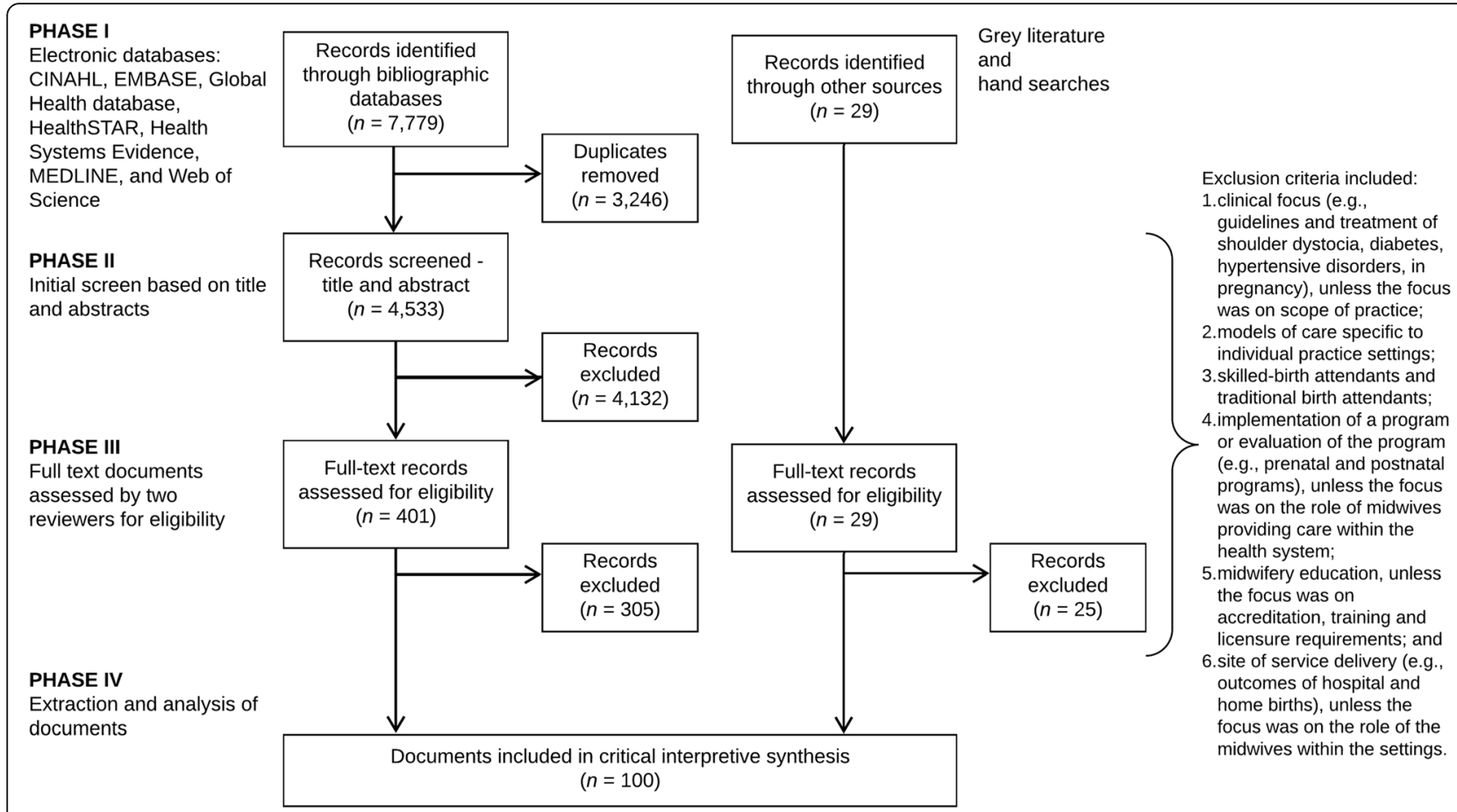

Fig. 1 Literature search and study selection flow diagram

of health care $(\mathrm{MeSH})$, and midwi* AND standards $(\mathrm{MeSH})$.

The second phase, complementary to the bibliographic database search, was a search of policy and health systems-related SRHR and midwifery organisation websites for relevant documents (e.g. World Health Assembly resolutions and United Nations Population Fund's State of the World's Midwifery reports). In addition, hand searches of reference lists from key publications were used to identify further relevant literature (e.g. 2014 Lancet Series on Midwifery). The final step in the literature search process was a purposive search to identify literature to fill the conceptual gaps that emerged.

\section{Article selection}

For inclusion, the documents had to relate specifically to trained midwives, with leeway in terms of title (e.g. certified nurse-midwives and certified midwives in the United States). Articles were included, that in addition to providing insight into the compass question, also (1) incorporated a range of perspectives across different countries; (2) integrated different concepts into one document; and (3) included perspectives on the compass question from other disciplines (e.g. geographic information system and other techniques to map the distribution of the midwifery workforce). In order to incorporate a broad range of documents, there were no limits placed on the searches such as regarding language or publication year.

An explicit set of exclusion criteria were developed by the research team to remove the documents that were not relevant to the aims of the study and did not link to the compass question. Exclusion criteria included documents (1) with a clinical focus (e.g. clinical guidelines, pharmacology, diagnostics, devices, surgery and/or treatment of shoulder dystocia, diabetes, hypertensive disorders, in pregnancy), unless the focus was on scope of practice (e.g. midwives working in expanded scopes); (2) focused on models of care that were specific to individual practices or hospitals and included those that were related to health system approaches; (3) relating to unskilled workers providing SRHR (e.g. traditional birth attendants); (4) focused on implementation of a programme or evaluation of the programme (e.g. prenatal and postnatal programmes), unless the focus was on the roles of midwives providing care within the health system; (5) focused on midwifery education, unless the focus was on accreditation, training and licensure requirements; and (6) focused on site of service delivery (e.g. outcomes of hospital and home births), unless the focus was on the roles of midwives within the different practice settings.

Once the series of searches were completed, an Endnote database was created to store and manage the results. All the duplicates were removed from the database and an initial review of the titles and abstracts was 
performed for each entry by the principal investigator (CAM) and records were classified as 'possibly include' or 'exclude'. In the first stage of screening, records were marked as 'possibly include' if they provided insight into the study's compass question. Full-text copies of the remaining records were retrieved and uploaded to Covidence, an online tool for systematic reviews, for final screening [27].

The last stage of screening involved two phases and consisted of full-text review by three reviewers (CAM, $\mathrm{TD}$ and $\mathrm{KMB}$ ). Using Covidence, each reviewer examined the records independently to assess inclusion. Any discrepancies were discussed and resolved. The reviewers prioritised the inclusion of empirical articles where possible, including empirical qualitative studies, which are the types of articles most likely to address political and health system components.

\section{Data analysis and synthesis}

A coding structure was created to guide the data extraction. The areas of expertise of the authors (health systems and policy, clinical practice and political science) informed the selection of frameworks guiding the data extraction. The political system factors were informed through the 3i framework, which is a broad typology that recognises the complex interplay among institutions, interests, and ideas and provides a way of organising the many factors that can influence policy choices [24, 28-30]. Institutions are made up of government structures (e.g. federal versus unitary government), policy legacies (e.g. the roles of past policies) and policy networks (e.g. relationships between actors around a policy issue). Interests can include a range of actors who may face (concentrated or diffuse) benefits and costs with particular courses of action, whereas ideas relate to peoples' beliefs (including those based on research evidence) and values.

'Health system arrangements' were informed through an established taxonomy developed by the McMaster Health Forum that includes (1) governance arrangements (e.g. policy authority, organisational authority and professional authority); (2) financial arrangements (e.g. how systems are financed and health professionals remunerated); (3) delivery arrangements (e.g. how care meets consumers' needs, who provides the care and where it is provided); and (4) implementation strategy (consumer- or provider-targeted strategies) [25]. The components of the framework for quality maternal and newborn care (practice categories, organisation of care, values, philosophy and health professionals) were incorporated into the health system arrangements coding structure to yield insights specific to midwifery care [3].
In addition to the frameworks that guided data extraction, further data was collected on publication year, study design and jurisdiction(s) of focus. A data extraction form was developed based on all of the concepts covered in the frameworks as well as the additional descriptive items.

The critical interpretive synthesis was conducted on the high value articles - those that yielded the most insight into the compass question. The reviewers prioritised the inclusion of empirical articles that were conceptually rich or integrated different concepts, filled disciplinary gaps, captured a breadth of perspectives across different countries or applied approaches outside of health. The articles were read by the principal investigator (CAM) and one- or two-page detailed summaries were created for each article. The summaries were coded using the qualitative software NVivo for Mac, which facilitates the organisation and coding of the data [31]. Coding was informed by the three key frameworks guiding the analysis and outlined above: $3 \mathrm{i}$ framework, 'health system arrangements' and components of the framework for quality maternal and newborn care.

Three steps were involved in the analysis for the critical interpretive synthesis. First, the summaries of the articles were coded based on the coding structure outlined in the data extraction form. Using a constant comparative method, emerging data were compared to previously collected data to find similarities and differences [32, 33]. The approach included observations on the terms and concepts used to describe midwifery within the health system as well as relationships between the concepts. For example, how the role of midwives within the health system is influenced by policy legacies (i.e. institutions), which is related to problems with collaborative/ interprofessional environments (i.e. delivery arrangements, skill mix and interprofessional teams). Second, all the data collected under each code was reviewed and more detailed notes of the concepts that emerged were included in the analysis. Lastly, themes were created for the concepts that emerged throughout the analysis.

Completeness of the findings was ensured through ongoing consultation with members of the research team. Central concepts and emerging themes of the study were discussed as a team and applied to current scholarship within the field of health systems and policy.

\section{Results}

\section{Search results and article selection}

A total of 7779 records were identified through the searches of electronic bibliographic databases. Once duplicates were removed $(n=3246)$, the remaining records $(n=4533)$ were screened based on title, abstract and the explicit set of exclusion criteria outlined above, leaving 401 potentially relevant records. In addition to the 
electronic database search, 29 records were purposively sampled for inclusion through grey literature and hand searches. The remaining 401 documents from the electronic database searches and 29 documents from the grey literature and hand searches were assessed by the reviewers (CAM, TD and $\mathrm{KMB}$ ) for inclusion using the full text. A total of 100 documents were included in the critical interpretive synthesis (Fig. 1).

Over three-quarters (79\%) of the documents were published after 2010, with no documents published prior to 2000. Of the 100 documents, the majority were primary research $(n=78)$, which were mostly qualitative research $(n=24)$ and observational studies $(n=24)$, followed by the 'other' category $(n=18)$ (e.g. geographic information systems research), systematic reviews $(n=15)$ and mixed methods $(n=4)$, while 1 was a randomised control trial. The remaining documents were categorised as nonresearch $(n=22)$, meaning that the approaches taken in the documents were either not systematic or that the methods were not reported transparently. Of the nonresearch documents, 8 were theoretical papers, 7 were reviews (non-systematic), 4 were 'other' (e.g. World Health Assembly resolutions, toolkits, etc.), and the remaining 3 were editorials. Forty-one of the documents focused on LMIC settings, followed by 35 on HIC settings, and 24 focused on both HIC and LMIC settings.

The results of the critical interpretive synthesis focused on the political and health system factors that influenced the roles of midwives within health systems. Table 1 focuses on the political system factors that emerged from the analysis and presents the relevant themes, relationships with other factors, and key examples from the literature of the factors that acted as either barriers or facilitators to the roles of midwives within the health system. Similarly, Table 2 focuses on the health system factors and presents the relevant themes, relationships with other factors, and key examples from the literature on the 'health system arrangements' that either acted as barriers or facilitators to the roles of midwives.

Three main findings emerged from the analysis on political system factors. First, within institutions, the effects of past policies regarding the value of midwives created interpretive effects, shaping the way midwifery care is organised in the health system. The legacies of these policies created barriers, which include SRHR policies that reinforced structural gender inequalities as well as, in a medical model, payment systems privileging physician-provided and hospital-based services [11, 13, $34,41-45,47-52,54-59,61-63,65]$.

Second, interest groups played an important role in either supporting or opposing the integration of midwifery in the health system. These groups can have direct or indirect influence and policies that provide concentrated benefits and diffuse costs for groups are more likely to move forward [24]. Interest groups advanced the integration of midwifery in the health system by (1) creating partnerships to improve SRHR [45, 67]; (2) promoting regulation and accreditation (e.g. accreditation requirements, setting standards, policies and guidelines) [63, 68-70]; (3) capacity-building including midwifery research [71, 72]; (4) policy leadership and decision-making [43]; and (5) lobbying governments and advocacy $[73,74]$. Strong leadership from midwifery professional associations engaged in policy dialogue and decisionmaking has helped advance agendas related to universal health coverage and meeting health-related United Nations Sustainable Development Goals [8, 63, 66, 71, 90].

Third, the most relevant themes related to ideas that emerged from the analysis pertained to societal values regarding gender (women's roles within society) as well as the medical model (historical medicalisation of the birth process and associated growth of physician-provided and hospitalbased care). We recognise the importance of gender-inclusive language but have use the term 'women' in this publication to reflect how gender is referenced in the documents reviewed. Barriers created by societal values included (1) social construction of gender and the status of midwives in a given jurisdiction often reflected the value placed on women within society (i.e. 'gender penalty') $[8,11,41,43,46,48,61$, 71]; (2) some cultures and beliefs did not allow women to receive care from men, yet there were few health professionals who were women due to lack of educational opportunities and societal values that restrict women from participating in the paid labour force [45]; and (3) health system priorities and shifting societal values favoured the medical model [41, 48-50, 75, 78, 99-101]. Examples of facilitators included Nordic health systems that value nonmedical models and women-dominated professional groups [37], which respect the right to informed choice [86].

Within health system factors, the main themes that emerged from the literature are presented according to 'health system arrangements'. First, within governance arrangements, regulation and accreditation mechanisms to support midwifery education programmes and institutional capacities were central to how midwives are integrated into health systems [63, 70, 93, 107]. The lack of legislation to support regulatory activities $[34,43,48,58$, $71,82,87,93,94]$ limited recognition and scope [38, 87] and the ability for midwives to practice as an autonomous profession [80]. Globally, there was a general lack of knowledge regarding the International Confederation of Midwives' Global Standards for Midwifery Education, which was a barrier to the provision of quality midwifery education [53, 66, 87, 107, 108]. Within financial arrangements, the literature focused primarily on how systems are financed, on the inclusion of midwifery services within financing systems and on the remuneration of 
Table 1 Political system factors that influence the roles of midwives within the health system

\begin{tabular}{|c|c|c|c|c|c|}
\hline \multirow{2}{*}{$\begin{array}{l}\text { Political system } \\
\text { factors }\end{array}$} & \multirow[t]{2}{*}{ Relevant themes } & \multirow{2}{*}{$\begin{array}{l}\text { Relationships with other } \\
\text { factors }\end{array}$} & \multicolumn{2}{|c|}{ Key examples from the literature } & \multirow[t]{2}{*}{ Sources } \\
\hline & & & Barriers & Facilitators & \\
\hline \multicolumn{6}{|l|}{ Institutions } \\
\hline $\begin{array}{l}\text { Government } \\
\text { structures }\end{array}$ & $\begin{array}{l}\text { - Indigenous self- } \\
\text { government allows } \\
\text { communities to make } \\
\text { decisions and imple- } \\
\text { ment midwifery services }\end{array}$ & $\begin{array}{l}\text { - Variation in government } \\
\text { structures can lead to } \\
\text { differences in midwifery } \\
\text { policy - relates to policy } \\
\text { instruments (legislation } \\
\text { and regulation) }\end{array}$ & - & $\begin{array}{l}\text { - Self-government and } \\
\text { political autonomy in } \\
\text { Nunavik helped Inuulitsi- } \\
\text { vik implement midwifery } \\
\text { services during a time } \\
\text { where midwifery was } \\
\text { not a regulated profes- } \\
\text { sion (Canada) [34-36] }\end{array}$ & [34-39] \\
\hline $\begin{array}{l}\text { Policy } \\
\text { legacies }\end{array}$ & $\begin{array}{l}\text { - Past policies about the } \\
\text { value of midwives } \\
\text { creates interpretive } \\
\text { effects, shaping the way } \\
\text { midwifery care is } \\
\text { organised in the health } \\
\text { system } \\
\text { - Values include SRHR } \\
\text { policies that reinforce } \\
\text { structural gender } \\
\text { inequalities in a medical } \\
\text { model, payment } \\
\text { systems privileging } \\
\text { physician-provided and } \\
\text { hospital-based services }\end{array}$ & $\begin{array}{l}\text { - Policy legacies ties } \\
\text { closely to ideas as the } \\
\text { values/mass opinion } \\
\text { about 'what ought to } \\
\text { be' are shaped by } \\
\text { legacies of gender } \\
\text { equality/inequality and } \\
\text { vice versa }\end{array}$ & 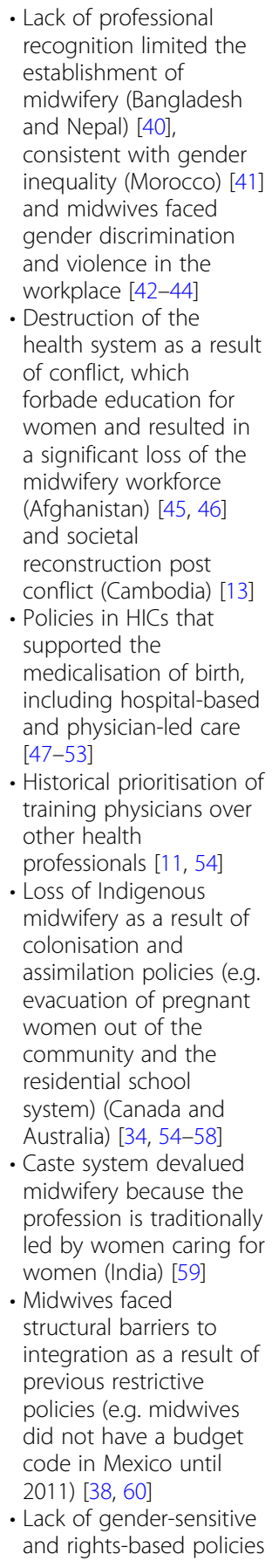 & $\begin{array}{l}\text { - Policy legacies that } \\
\text { valued midwives and } \\
\text { home births influenced } \\
\text { the way the health } \\
\text { system was organised } \\
\text { (Netherlands) [49] } \\
\text { - Midwifery as a tool to } \\
\text { empower women and } \\
\text { advance gender equality } \\
\text { [61] } \\
\text { - Professionalisation of } \\
\text { midwifery began in the } \\
\text { eighteenth century } \\
\text { (Sweden) [62] } \\
\text { - Universal Rights of } \\
\text { Childbearing Women in } \\
\text { the Respectful Maternity } \\
\text { Care Charter, recognised } \\
\text { that issues related to } \\
\text { gender equity and } \\
\text { gender violence were at } \\
\text { the centre of maternity } \\
\text { care - 'safe motherhood' } \\
\text { extends to basic human } \\
\text { rights for pregnant } \\
\text { women [42, 63, 64] } \\
\text { - The State of the World's } \\
\text { Midwifery 2014 was a } \\
\text { global policy initiative } \\
\text { that increased the status } \\
\text { of midwifery at country } \\
\text { levels and international } \\
\text { policy dialogue [65, 66] }\end{array}$ & {$[11,13,34,40-66]$} \\
\hline
\end{tabular}


Table 1 Political system factors that influence the roles of midwives within the health system (Continued)

\begin{tabular}{|c|c|c|c|c|c|}
\hline \multirow{2}{*}{$\begin{array}{l}\text { Political system } \\
\text { factors }\end{array}$} & \multirow[t]{2}{*}{ Relevant themes } & \multirow{2}{*}{$\begin{array}{l}\text { Relationships with other } \\
\text { factors }\end{array}$} & \multicolumn{2}{|c|}{ Key examples from the literature } & \multirow[t]{2}{*}{ Sources } \\
\hline & & & Barriers & Facilitators & \\
\hline & & & $\begin{array}{l}\text { reinforced structural } \\
\text { gender inequalities (i.e. } \\
\text { created barriers to re- } \\
\text { spectful maternity care } \\
\text { and participation in } \\
\text { policy-making) [42-44] }\end{array}$ & & \\
\hline Interests & $\begin{array}{l}\text { - Interests include societal } \\
\text { interest groups (e.g. } \\
\text { consumer and religious } \\
\text { groups), researchers, } \\
\text { professional and } \\
\text { international } \\
\text { associations, and donor } \\
\text { agencies } \\
\text { - Policies are influenced } \\
\text { by interests that have } \\
\text { concentrated benefits } \\
\text { and diffuse costs } \\
\text { - Interest groups play a } \\
\text { role in supporting or } \\
\text { opposing the } \\
\text { integration of midwifery } \\
\text { in the health system } \\
\text { - In LMICs, bilateral and } \\
\text { multilateral donors work } \\
\text { alongside local } \\
\text { governments } \\
\text { - In HICs, professional } \\
\text { associations play a } \\
\text { strong role in political } \\
\text { lobbying }\end{array}$ & $\begin{array}{l}\text { - Interests are closely } \\
\text { related to institutions } \\
\text { (policy networks) as well } \\
\text { as ideas as interest } \\
\text { groups often reflect } \\
\text { and/or can influence } \\
\text { societal values } \\
\text { - Interest groups play an } \\
\text { important role in } \\
\text { advancing midwifery in } \\
\text { the health system by (1) } \\
\text { creating partnerships to } \\
\text { improve SRHR [45, 67]; } \\
\text { (2) promoting regulation } \\
\text { and accreditation (e.g. } \\
\text { accreditation } \\
\text { requirements, setting } \\
\text { standards, policies and } \\
\text { guidelines) [63, 68-70]; } \\
\text { (3) capacity-building, in- } \\
\text { cluding midwifery re- } \\
\text { search [71, 72]; (4) policy } \\
\text { leadership and decision- } \\
\text { making [43]; and (5) } \\
\text { lobbying governments/ } \\
\text { advocacy [73, 74] }\end{array}$ & $\begin{array}{l}\text { - Strong physician and } \\
\text { hospital interest groups } \\
\text { created a monopoly } \\
\text { over maternity care } \\
\text { (United States, Canada, } \\
\text { Australia, and Mexico) } \\
\text { [37, 38, 51, 55, 75-77] } \\
\text { and impede midwives } \\
\text { from practicing to their } \\
\text { full scope [78, 79] } \\
\text { - Tensions within the } \\
\text { profession between } \\
\text { nurse midwives and } \\
\text { midwives (United States) } \\
\text { [80] } \\
\text { - Marginalisation of } \\
\text { midwifery through } \\
\text { dominant stakeholder } \\
\text { groups [50] } \\
\text { - Competing interests } \\
\text { from nursing } \\
\text { organisations created } \\
\text { interprofessional } \\
\text { tensions (Nepal) and } \\
\text { limited establishing } \\
\text { midwifery as an } \\
\text { independent profession } \\
\text { [81] } \\
\text { - Barriers existed in } \\
\text { accessing evidence } \\
\text { published by African } \\
\text { midwives (e.g. African } \\
\text { nursing and midwifery } \\
\text { research is often } \\
\text { published in non- } \\
\text { indexed journals) [72] }\end{array}$ & 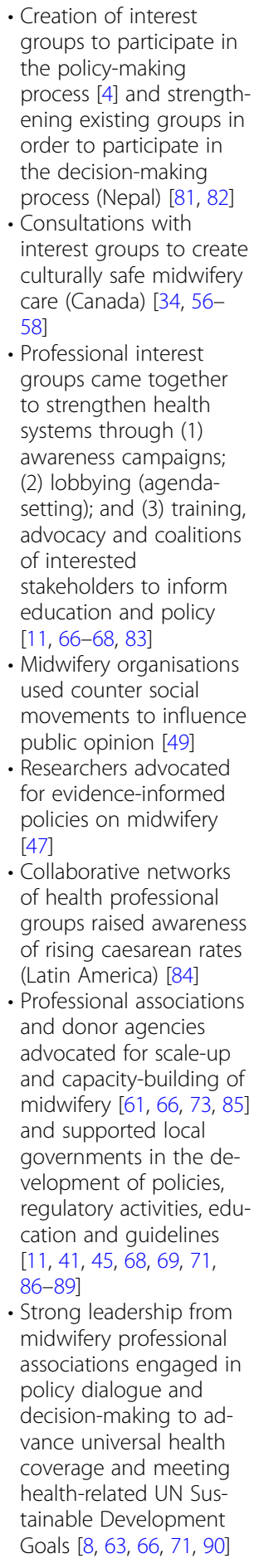 & $\begin{array}{l}{[1,4,6,8,11,12,34,} \\
35,37,38,45,47, \\
50,51,55,57-59, \\
61,63,66,67,69, \\
70,72,73,75-78, \\
80,81,83,85-91, \\
93-98]\end{array}$ \\
\hline
\end{tabular}


Table 1 Political system factors that influence the roles of midwives within the health system (Continued)

\begin{tabular}{|c|c|c|c|c|c|}
\hline \multirow{2}{*}{\multicolumn{2}{|c|}{$\begin{array}{l}\text { Political system Relevant themes } \\
\text { factors }\end{array}$}} & \multirow{2}{*}{$\begin{array}{l}\text { Relationships with other } \\
\text { factors }\end{array}$} & \multicolumn{2}{|c|}{ Key examples from the literature } & \multirow[t]{2}{*}{ Sources } \\
\hline & & & Barriers & Facilitators & \\
\hline & & & & $\begin{array}{l}\text { - Equitable alliance } \\
\text { between midwifery and } \\
\text { physician groups } \\
\text { (Sweden) [62] and } \\
\text { collaborative } \\
\text { professional } \\
\text { development (United } \\
\text { Kingdom) [76] } \\
\text { - Increase in the number } \\
\text { of midwifery } \\
\text { professional associations } \\
\text { in LMICs, which were } \\
\text { enablers to advocacy } \\
\text { and linking policy and } \\
\text { implementation [87, 91] } \\
\text { - Twinning (Tanzania } \\
\text { Midwives Association } \\
\text { and the Canadian } \\
\text { Association of Midwives) } \\
\text { strengthened midwifery } \\
\text { professional associations } \\
\text { and increased midwifery } \\
\text { capacity [92] } \\
\text { - Increase of research } \\
\text { capacity by midwives } \\
\text { supported teaching and } \\
\text { clinical practice [72, 93] }\end{array}$ & \\
\hline
\end{tabular}

Ideas $\quad$ Societal values regarding gender equality (e.g. women's roles within society) as well as the medical model (e.g. the medicalisation of the birth process and associated valuing of physician and hospitalbased care)
- Ideas relate to both political and health system factors by influencing the values of citizens and either valuing or devaluing gender and the medical model
- Social construction of gender - the status of midwives in a given jurisdiction often reflected the value placed on women within the society (i.e. 'gender penalty') $[8,11$, $41,43,46,48,61,71]$

- Some cultures did not allow women to receive care from men yet there were few health professionals that were women due to lack of educational

opportunities [45]

- Health system priorities as well as changing values were based on the medical model and normalisation of medical interventions, which favoured care by physicians and within hospital settings $[41,48-$ 50, 75, 78, 99-101]

- Incongruence between international recommendations for skilled birth attendants and needs of Mayan population in Guatemala for intercultural healthcare from traditional birth attendants [102]
- Nordic maternity care systems' non-medical models and women dominated professional groups [37]; respect of gender equality and informed choice [86]

- Increasing consumer demand for midwiferyled care [77]

- Reclaiming Indigenous midwifery and bringing birth back to the community (Canada and Guatemala) [35, 103]
[1, 3, 6-8, 10-13, 35, $37,38,41-43,45-$ $50,54-58,61,62$,

$68,71,75,77,78$,

$84,86,94,95,97$,

$99,100,102-105]$ 
Table 2 Health system arrangements that influence the roles of midwives within the health system

\begin{tabular}{|c|c|c|c|c|c|}
\hline \multirow{2}{*}{$\begin{array}{l}\text { Health } \\
\text { system } \\
\text { arrangements }\end{array}$} & \multirow[t]{2}{*}{ Relevant themes } & \multirow{2}{*}{$\begin{array}{l}\text { Relationships with other } \\
\text { factors }\end{array}$} & \multicolumn{2}{|c|}{ Key examples from the literature } & \multirow[t]{2}{*}{ Sources } \\
\hline & & & Barriers & Facilitators & \\
\hline $\begin{array}{l}\text { Governance } \\
\text { arrangements }\end{array}$ & $\begin{array}{l}\text { - Mechanisms to support } \\
\text { accountability for state } \\
\text { sector's role in } \\
\text { financing and delivery } \\
\text { - The regulatory process } \\
\text { (or lack thereof) of the } \\
\text { profession is central to } \\
\text { the roles of midwives } \\
\text { within the health } \\
\text { system and many } \\
\text { references covered } \\
\text { regulation as well as } \\
\text { barriers to regulation } \\
\text { - Accreditation systems } \\
\text { to establish quality } \\
\text { education } \\
\text { - Enabling professional } \\
\text { environments support } \\
\text { the International } \\
\text { Confederation of } \\
\text { Midwives' three pillars } \\
\text { (education, regulation } \\
\text { and professional } \\
\text { association) } \\
\text { - Scope of practice - } \\
\text { expanding scope or } \\
\text { restrictions to practicing } \\
\text { to full scope }\end{array}$ & $\begin{array}{l}\text { - Within governance } \\
\text { arrangements, } \\
\text { regulatory process } \\
\text { overlaps with: } \\
\text { - organisational } \\
\text { authority - } \\
\text { accreditation and } \\
\text { - professional authority } \\
\text { - training and } \\
\text { licensure } \\
\text { requirements, and } \\
\text { scope of practice } \\
\text { - Regulatory process } \\
\text { overlaps with 'ideas' } \\
\text { and in some cases self- } \\
\text { regulation was a re- } \\
\text { sponse to growing } \\
\text { consumer demand for } \\
\text { midwifery services [3] }\end{array}$ & 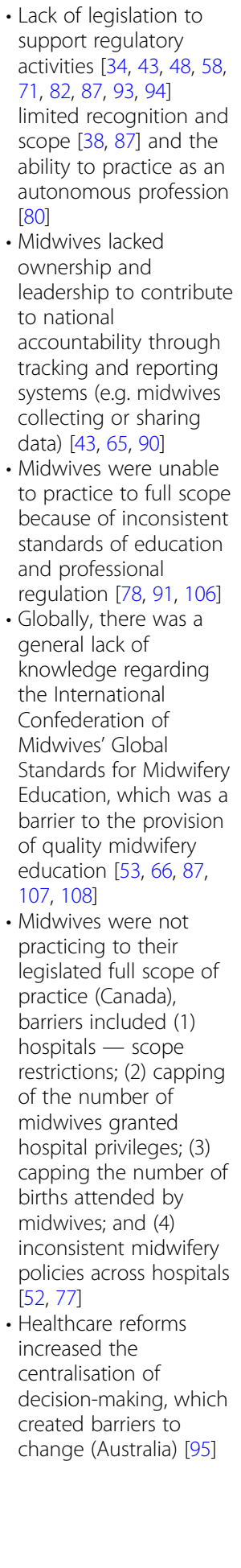 & $\begin{array}{l}\text { - Combination of } \\
\text { regulatory processes } \\
\text { and health systems that } \\
\text { promoted birth as a } \\
\text { natural process; } \\
\text { favoured professional } \\
\text { midwifery care (Nordic } \\
\text { countries) [8, 62, 86, 91, } \\
\text { 99] } \\
\text { - Accreditation } \\
\text { mechanisms supported } \\
\text { midwifery education } \\
\text { programmes and } \\
\text { institutional capacities } \\
\text { [63, 70, 93, 107] } \\
\text { - Environments that } \\
\text { allowed midwives to } \\
\text { practice autonomously } \\
\text { and to full scope of } \\
\text { practice [74] } \\
\text { - Expanded scope from } \\
\text { providing skilled } \\
\text { delivery care to include } \\
\text { SRHR ranging from } \\
\text { abortion, family } \\
\text { planning, screening } \\
\text { (diabetes and several } \\
\text { forms of cancer), } \\
\text { immunisations, } \\
\text { palliative care, and } \\
\text { public health and } \\
\text { promotion [10-13, 55, } \\
74,94,109-113] \\
\text { - Increased contraceptive } \\
\text { prevalence rate } \\
\text { (Nigeria) by engaging } \\
\text { midwives in provision } \\
\text { of family planning } \\
\text { services [114] } \\
\text { - Engagement of } \\
\text { midwives within } \\
\text { broader humanitarian } \\
\text { emergency contexts } \\
\text { (e.g. conflict, epidemics, } \\
\text { and natural disasters) } \\
\text { [46] } \\
\text { - Effective collaborationation and and } \\
\text { infional health } \\
\text { information systems } \\
\text { supported monitoring governmental } \\
\text { institutions and } \\
\text { professional } \\
\text { and evaluation } \\
\text { processes for evidencions supported } \\
\text { informed decisions [63] } \\
\text { intity midwifery }\end{array}$ & $\begin{array}{l}{[1-4,6,8,10-13,34,35} \\
38,39,43,45-48,50,52 \\
53,55,56,58,59,62,63 \\
65,68-71,74,77,78,80 \\
82,84,86,87,90,91,93- \\
100,105-109,111-116]\end{array}$ \\
\hline
\end{tabular}

Financial arrangements

Financing - Financing systems: (1) • Relates to 'governance • Marginalisation of • Supportive policies systems Medicare has been arrangements' midwifery through
- Supportive policies
were implemented
$[1,2,6,10,13,35,38,39$, $43,50,55-59,61,69,73$, 
Table 2 Health system arrangements that influence the roles of midwives within the health system (Continued)

\begin{tabular}{|c|c|c|c|c|c|}
\hline \multirow{2}{*}{$\begin{array}{l}\text { Health } \\
\text { system } \\
\text { arrangements }\end{array}$} & \multirow[t]{2}{*}{ Relevant themes } & \multirow{2}{*}{$\begin{array}{l}\text { Relationships with other } \\
\text { factors }\end{array}$} & \multicolumn{2}{|c|}{ Key examples from the literature } & \multirow[t]{2}{*}{ Sources } \\
\hline & & & Barriers & Facilitators & \\
\hline & $\begin{array}{l}\text { funded by a mix of } \\
\text { federal government } \\
\text { cash payment to } \\
\text { provinces, province- } \\
\text { specific taxes and } \\
\text { federal government } \\
\text { (Canada) [6]; (2) mixed } \\
\text { health system - public } \\
\text { and private financing, } \\
\text { health insurance, and } \\
\text { service delivery and the } \\
\text { public system is } \\
\text { supported by the } \\
\text { National Health Fund, } \\
\text { which covers almost } \\
75 \% \text { of the population } \\
\text { (Chile) [84]; and (3) } \\
\text { effective coverage - } \\
\text { the proportion of the } \\
\text { population who need } \\
\text { the intervention and } \\
\text { receive it [1] }\end{array}$ & $\begin{array}{l}\text { (accountability in the } \\
\text { state sector's roles in } \\
\text { financing and delivery) }\end{array}$ & $\begin{array}{l}\text { reframing maternity } \\
\text { care to focus on patient } \\
\text { safety and costs of } \\
\text { medical malpractice } \\
\text { (United States) [50] and } \\
\text { shifting of professional } \\
\text { role boundaries } \\
\text { between obstetricians } \\
\text { and midwives [101] } \\
\text { - Changes in the 1970s } \\
\text { to the Canadian } \\
\text { northern health services } \\
\text { resulted in the } \\
\text { evacuation of women } \\
\text { from remote } \\
\text { communities to } \\
\text { hospitals in larger } \\
\text { centres for childbirth } \\
\text { [35] } \\
\text { - Economic barriers to } \\
\text { the provision of quality } \\
\text { midwifery care included } \\
\text { low or absent wages } \\
\text { (e.g. waiting up to } 6 \\
\text { months for public } \\
\text { salary), lack of financing } \\
\text { systems through } \\
\text { governmental support, } \\
\text { obligatory user fees and } \\
\text { reimbursement by fee } \\
\text { exemption schemes } \\
\text { [43] }\end{array}$ & $\begin{array}{l}\text { through community- } \\
\text { based and institutional } \\
\text { healthcare services, } \\
\text { which expanded across } \\
\text { the country and were } \\
\text { free (reaching most re- } \\
\text { mote and rural areas) } \\
\text { (Sri Lanka) [69] } \\
\text { - The Government } \\
\text { Midwifery Incentive } \\
\text { Scheme, a nationwide } \\
\text { results-based financing } \\
\text { initiative increased (1) } \\
\text { health system perform- } \\
\text { ance; (2) facility deliver- } \\
\text { ies; and (3) skilled birth } \\
\text { attendance (Cambodia) } \\
\text { [115] } \\
\text { - Incentivising facility } \\
\text { deliveries through } \\
\text { governmental initiatives } \\
\text { to remunerate } \\
\text { midwives and providing } \\
\text { incentives to both the } \\
\text { health professional and } \\
\text { the client (Cambodia) } \\
\text { [13, 115] } \\
\text { - Maternity care reform } \\
\text { enabled midwives to } \\
\text { access Medicare and } \\
\text { the Pharmaceutical } \\
\text { Benefits Scheme } \\
\text { (Australia) }\end{array}$ & $\begin{array}{l}74,76,80,84,95,101 \\
104,109,115]\end{array}$ \\
\hline $\begin{array}{l}\text { Delivery } \\
\text { arrangements }\end{array}$ & $\begin{array}{l}\text { - The roles of midwives } \\
\text { in health services } \\
\text { delivery } \\
\text { - Delivery arrangements } \\
\text { relate to (1) access } \\
\text { midwifery care (e.g. } \\
\text { workforce supply, } \\
\text { distribution and } \\
\text { retention); (2) how care } \\
\text { is provided (e.g. task- } \\
\text { shifting, interprofes- } \\
\text { sional teams); and (3) } \\
\text { where care is provided } \\
\text { (e.g. hospital based, in- } \\
\text { tegration of services } \\
\text { and continuity of care) }\end{array}$ & $\begin{array}{l}\text { - Delivery arrangements } \\
\text { link with 'institutions', } \\
\text { 'interests' and 'ideas' in } \\
\text { that they influence the } \\
\text { delivery of healthcare } \\
\text { services }\end{array}$ & $\begin{array}{l}\text { - Unmet need for SRHR } \\
\text { services in sub-Saharan } \\
\text { Africa due to health } \\
\text { workforce supply and } \\
\text { demographic trends } \\
\text { [117] } \\
\text { - Re-emergence of trad- } \\
\text { itional midwives as a re- } \\
\text { sult of limited skilled } \\
\text { birth attendant work- } \\
\text { force [46] } \\
\text { - Midwives experienced } \\
\text { role strain due to } \\
\text { increasing workloads } \\
\text { [48], burn out [43, 118] } \\
\text { and lack of support to } \\
\text { practice autonomously } \\
\text { [75, 104] leads to } \\
\text { disempowerment [43] } \\
\text { - Lack of equipment in } \\
\text { schools and facilities } \\
\text { can create gaps in } \\
\text { teaching quality and } \\
\text { practice [119] } \\
\text { - Medical model } \\
\text { prioritised physician-led } \\
\text { care in hospitals and } \\
\text { created friction be- } \\
\text { tween midwives and } \\
\text { physicians [38, 50, 52] } \\
\text { and also minimised the } \\
\text { roles of midwives in pri- } \\
\text { mary care [99] }\end{array}$ & $\begin{array}{l}\text { - Collaborative care } \\
\text { involved } \\
\text { interprofessional groups } \\
\text { (e.g. midwives working } \\
\text { with physicians and } \\
\text { nurses) [10, 34, 55, 74, } \\
75,100,116] \\
\text { - Based on statistical } \\
\text { modelling, the } \\
\text { projected effect of } \\
\text { scaling-up midwifery } \\
\text { will deliver the most } \\
\text { impact on maternal, } \\
\text { newborn and child } \\
\text { health [2, 73] } \\
\text { - Task-sharing of HIV, tu- } \\
\text { berculosis [96], } \\
\text { abortion-related (medi- } \\
\text { cation abortion and } \\
\text { vacuum aspiration abor- } \\
\text { tions) services to mid- } \\
\text { wives [12, 110, 111, 120] } \\
\text { - Midwifery (led by } \\
\text { Indigenous midwives) is } \\
\text { returning culturally safe } \\
\text { and appropriate SRHR } \\
\text { to Inuit communities } \\
\text { (Canada) [34-36, 54] } \\
\text { - Midwives increased } \\
\text { access to SRHR services } \\
\text { in fragile and conflict- } \\
\text { affected states [121, } \\
122]\end{array}$ & $\begin{array}{l}{[3,4,6,7,9-13,34-39,} \\
43,45,46,48,50,51,54, \\
55,58,59,61,62,69,73, \\
74,76,77,79,86,94,96, \\
97,99,100,104,105, \\
110,116-118,120-122]\end{array}$ \\
\hline
\end{tabular}


Table 2 Health system arrangements that influence the roles of midwives within the health system (Continued)

\begin{tabular}{|c|c|c|c|c|c|}
\hline \multirow{2}{*}{$\begin{array}{l}\text { Health } \\
\text { system } \\
\text { arrangements }\end{array}$} & \multirow[t]{2}{*}{ Relevant themes } & \multirow{2}{*}{$\begin{array}{l}\text { Relationships with other } \\
\text { factors }\end{array}$} & \multicolumn{2}{|c|}{ Key examples from the literature } & \multirow[t]{2}{*}{ Sources } \\
\hline & & & Barriers & Facilitators & \\
\hline & & & $\begin{array}{l}\text { - When compared with } \\
\text { eight HICs, midwifery in } \\
\text { Canada played a } \\
\text { relatively minor role in } \\
\text { the provision of SRHR } \\
\text { [6] } \\
\text { - Rising caesarean rates } \\
\text { in Latin America and } \\
\text { medically induced } \\
\text { labours [84] }\end{array}$ & & \\
\hline
\end{tabular}

HICS high-income countries, SRHR sexual and reproductive health and rights

midwives that is reflective of scope of practice $[1,2,6$, $10,13,35,38,39,43,50,55-59,61,69,73,74,76,80$, $84,95,101,104,109,115]$. Lastly, the main themes relating to delivery arrangements focused on (1) accessing midwifery care ranging from availability and timely access to workforce supply, distribution and retention; (2) by whom care is provided (e.g. task-sharing and interprofessional teams); and (3) where care is provided (e.g. hospital-based, integration of services and continuity of care) $[3,4,6,7,9-13,34-39,43,45,46,48,50,51,54$, $55,58,59,61,62,69,73,74,76,77,79,86,94,96,97$, $99,100,104,105,110,116-118,120-122]$.

\section{Theoretical framework}

Figure 2 brings together the main findings from the critical interpretive synthesis and presents a theoretical framework, which can be thought of as a heuristic that can be used to map the key elements that influence midwives' roles in a particular political and health system. The factors presented in the framework are not weighted but rather present the range of variables influencing the level of integration of the profession. The cumulative effects of the barriers presented on the right-hand side of the framework lead to health systems where the profession is disempowered and midwives exist on the margins with very limited capacity. Some of the variables and examples presented in the framework have context specificity to reflect findings from the critical interpretive synthesis (e.g. self-regulated profession, Indigenous selfgovernment, Nordic maternity care systems, and payment systems privileging physician-provided and hospital-based services in some contexts).

\section{Discussion}

\section{Principal findings}

Similar to the concept of WHO's health system 'building blocks', the political system factors presented in the theoretical framework form the bottom building block or the foundation for the 'health system arrangements', acting as either a barrier or facilitator. For example, favourable institutional factors (e.g. policy legacies that value midwifery as a profession), interests (e.g. collaborative interest groups coming together to reach a common goal) and ideas (e.g. societal values centring on gender equality and birth as a natural process) act as enablers to 'health system arrangements' that build on each other to support the integration of midwifery. Together, supportive political and health system factors lead to health systems where midwives practice to scope (i.e. trained, licensed and regulated according to international standards, working in collaborative/interprofessional settings with an established workforce). On the other hand, health systems that have many political and health system challenges will in turn have a limited midwifery workforce where midwives lack an institutional voice and representation in SRHR decision-making. Significant barriers limit the options available to the midwifery workforce and is most often reflected in siloed work settings with midwives working in the periphery of the health system.

\section{Strengths and limitations of the study}

The main strength of the study is the use of a critical interpretive synthesis. This is a relatively new systematic review methodology, which combines a rigorous systematic review of electronic bibliographic databases with iterative and purposive sampling of the literature to fill conceptual gaps. The approach incorporated a range of documents (empirical and non-empirical), which broadened the scope of the literature used to inform the theoretical framework.

The main limitation of the critical interpretive synthesis was that the search strategy may not have fully covered the diverse terminology used to refer to midwifery. However, the principal investigator (CAM) consulted with a librarian and team members to ensure that the search strategy was as inclusive as possible, which is also reflected by the high proportion of articles that were later excluded during the screening process. Meanwhile, the majority of articles retrieved from the searches were 


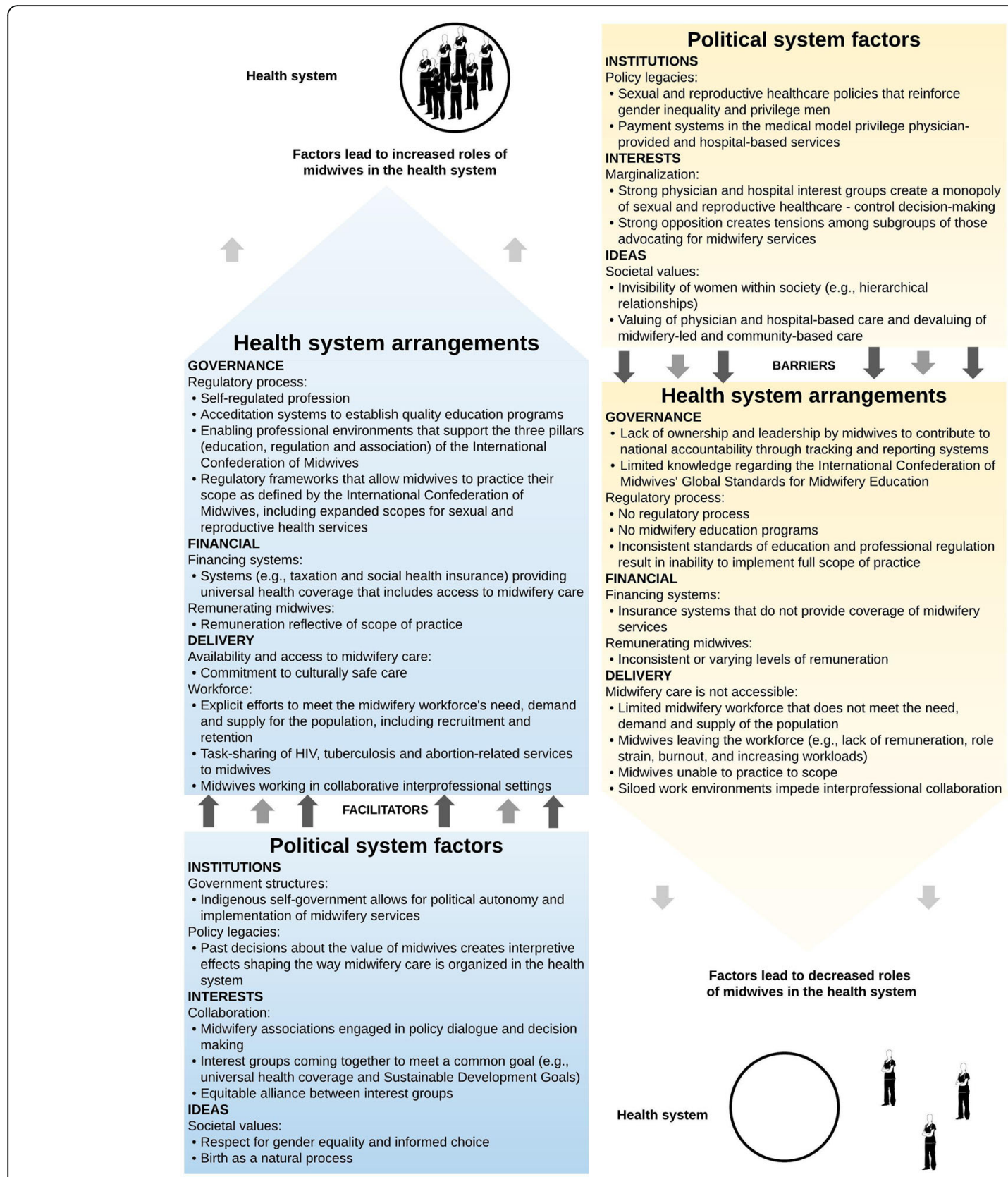

Fig. 2 Theoretical framework of the political and health system factors that influence the roles of midwives within the health system

published after 2000, which could be related to the release of the Millennium Development Goals and subsequent Sustainable Development Goals, and the wider attention given to SRHR on global agendas.

\section{Implications for policy and practice}

Any changes to the roles of midwifery in health systems needs to take into account the political system where decisions about their integration will be made as well as the nature of the health system in which they are being integrated. The theoretical framework is a tool that helps to inform such changes by identifying the drivers of midwives' roles that facilitate or constrain such integration. The study results have implications for policymakers as, firstly, the theoretical framework can be used to conduct an assessment of the factors in order to strengthen the profession by identifying the facilitators that can be leveraged as well as the barriers that can be addressed to support change. For example, Sweden has favourable political system conditions (e.g. policy legacies of professionalisation of midwives dating back to the eighteenth century and an equitable alliance between 
midwifery and physician groups), which is reflected in the health system arrangements where midwives are the primary health professionals for low-risk pregnant people. In contrast, the United States has policy legacies of payment systems valuing physician-provided and hospital-based care, strong physician and hospital interest groups have created a monopoly over sexual and reproductive health services, and existing tensions within the profession between nurse midwives and midwives.

Moving forward, an implication for practice is that changes to further enhance the role of midwives would require different types of policy levers. In looking at growing midwifery in LMICs, governments can use the tool to understand how to best influence the integration of the profession. This information will provide valuable experience and understanding of the contextual factors so that governments can best leverage their position when working with bilateral and multilateral funders to improve SRHR. Conversely, in the example of the United States, the framework presented helps to explain why midwives play such a small role in sexual and reproductive health service delivery in the United States. The tool highlights that funding and regulatory levers would need to be pulled; yet, strong policy legacies and entrenched interests present significant barriers. Change would require spending political capital to modify existing structures within the health system.

\section{Conclusions}

While research evidence on the role of midwives in the provision of high-quality SRHR has increased and the 2014 Lancet Series on Midwifery was key to raising the profile of midwifery research, significant gaps in the literature persist. Structural gender inequalities are reflected in the low status of midwifery in some contexts, which leads to poor political and health systems supports to invest in quality midwifery care [43]. Our findings show that the research evidence related to the roles of midwives within health systems is relatively saturated in terms of delivery arrangements yet surprisingly little is known about governance and financial arrangements and about implementation strategies, which are key to effectively integrating midwifery and pushing the field forward in meaningful ways.

\footnotetext{
Abbreviations

HICS: High-income countries; LMICs: Low- and middle-income countries; SRHR : Sexual and reproductive health and rights
}

\section{Acknowledgements}

The authors would like to thank Kirsty Bourret and Tomasso D'Ovidio for their assistance with assessing documents for eligibility and inclusion in the review.

\section{Authors' contributions}

CAM conceived the study design with her supervisor, JNL, and was responsible for all data collection and analysis. JNL, EKH, MGW and MLD provided content expertise (health systems and health policy, clinical practice and political science) to inform the selection of frameworks guiding the data extraction. All authors contributed to the development of the conceptual framework and approved the final manuscript.

\section{Funding}

There are no sources of funding to declare for this research.

\section{Availability of data and materials}

All data generated or analysed during this study are included in this published article and summarised in Tables 1 and 2.

Ethics approval and consent to participate

Not applicable.

Consent for publication

Not applicable.

\section{Competing interests}

The authors declare that they have no competing interests.

\section{Author details}

${ }^{1}$ Department of Obstetrics and Gynecology, McMaster Midwifery Research Centre, 1280 Main St. West, HSC-4H26, Hamilton, ON L8S 4K1, Canada. ${ }^{2}$ McMaster Health Forum, 1280 Main St West, MML-417, Hamilton, ON L8S 4L6, Canada. ${ }^{3}$ Department of Political Science, McMaster University, 1280 Main St. West, KTH-533, Hamilton, ON L8S 4M4, Canada.

Received: 27 January 2020 Accepted: 14 June 2020

Published online: 08 July 2020

\section{References}

1. ten Hoope-Bender P, de Bernis L, Campbell J, Downe S, Fauveau V, Fogstad $\mathrm{H}$, et al. Improvement of maternal and newborn health through midwifery. Lancet. 2014;384(9949):1226-35.

2. Homer CS, Friberg IK, Dias MA, ten Hoope-Bender P, Sandall J, Speciale AM, et al. The projected effect of scaling up midwifery. Lancet. 2014;384(9948): 1146-57.

3. Renfrew MJ, McFadden A, Bastos MH, Campbell J, Channon AA, Cheung NF, et al. Midwifery and quality care: findings from a new evidence-informed framework for maternal and newborn care. Lancet. 2014;384(9948):1129-45.

4. UNFPA. The State of the World's Midwifery 2014. Geneva: United Nations Population Fund; 2014.

5. Hutton EK, Cappelletti A, Reitsma AH, Simioni J, Horne J, McGregor C, et al. Outcomes associated with planned place of birth among women with lowrisk pregnancies. CMAJ. 2016:188(5):E80-90.

6. Malott AM, Davis BM, McDonald H, Hutton E. Midwifery care in eight industrialized countries: how does Canadian midwifery compare? J Obstet Gynaecol Can. 2009;31(10):974-9.

7. Sandall J, Soltani H, Gates S, Shennan A, Devane D. Midwife-led continuity models versus other models of care for childbearing women. Cochrane Database Syst Rev. 2013;8:CD004667.

8. Renfrew MJ, Ateva E, Dennis-Antwi JA, Davis D, Dixon L, Johnson P, et al. Midwifery is a vital solution-what is holding back global progress? Birth. 2019;46(3):396-9.

9. Malott AM, Kaufman K, Thorpe J, Saxell L, Becker G, Paulette L, et al. Models of organization of maternity care by midwives in Canada: a descriptive review. J Obstet Gynaecol Can. 2012;34(10):961-70.

10. Bartlett L, Weissman E, Gubin R, Patton-Molitors R, Friberg IK. The impact and cost of scaling up midwifery and obstetrics in 58 low- and middleincome countries. PLoS One. 2014:9(6):e98550.

11. Fauveau V, Sherratt DR, de Bernis L. Human resources for maternal health: multi-purpose or specialists? Hum Resour Health. 2008;6:21.

12. Holcombe SJ, Berhe A, Cherie A. Personal beliefs and professional responsibilities: Ethiopian midwives' attitudes toward providing abortion services after legal reform. Stud Fam Plan. 2015;46(1):73-95.

13. Liljestrand J, Sambath MR. Socio-economic improvements and health system strengthening of maternity care are contributing to maternal mortality reduction in Cambodia. Reprod Health Matters. 2012;20(39):62-72. 
14. ICM. International definition of the midwife. The Hague: International Confederation of Midwives; 2017. https:/www.internationalmidwives.org/ assets/files/definitions-files/2018/06/eng-definition_of_the_midwife-2017.pdf.

15. World Health Organization. Monitoring the building blocks of health systems: a handbook of indicators and their measurement strategies. Geneva: WHO; 2020. https://www.who.int/healthinfo/systems/WHO_ MBHSS_2010_full_web.pdf.

16. Lopes SC, Titulaer P, Bokosi M, Homer CS, ten Hoope-Bender P. The involvement of midwives associations in policy and planning about the midwifery workforce: a global survey. Midwifery. 2015;31(11):1096-103.

17. Janssen PA, Mitton C, Aghajanian J. Costs of planned home vs. hospital birth in British Columbia attended by registered midwives and physicians. PLoS One. 2015;10(7):e0133524.

18. Reinharz D, Blais R, Fraser WD, Contandriopoulos A-P. Cost-effectiveness of midwifery services vs. medical services in Quebec. Can J Public Health. 2000; 91(1):I12.

19. Schroeder E, Petrou S, Patel N, Hollowell J, Puddicombe D, Redshaw M, et al. Cost effectiveness of alternative planned places of birth in woman at low risk of complications: evidence from the Birthplace in England national prospective cohort study. BMJ. 2012;344:e2292.

20. Lavis J, Davies H, Oxman A, Denis JL, Golden-Biddle K, Ferlie E. Towards systematic reviews that inform health care management and policy-making. J Health Serv Res Policy. 2005;10(Suppl 1):35-48.

21. Lavis JN, Guindon GE, Cameron D, Boupha B, Dejman M, Osei EJ, et al. Bridging the gaps between research, policy and practice in low- and middle-income countries: a survey of researchers. CMAJ. 2010;182(9):E350-61.

22. Moat KA, Lavis JN, Abelson J. How contexts and issues influence the use of policy-relevant research syntheses: a critical interpretive synthesis. Milbank Q. 2013;91(3):604-48

23. Wilson MG, Moat KA, Lavis JN. The global stock of research evidence relevant to health systems policymaking. Health Res Policy Syst. 2013;11:32.

24. Lazar H, Lavis JN, Forest P-G, Church J. Paradigm freeze: why it is so hard to reform health care in Canada. Montreal: McGill-Queen's University Press; 2013.

25. Lavis JN, Wilson MG, Moat KA, Hammill AC, Boyko JA, Grimshaw JM, et al. Developing and refining the methods for a 'one-stop shop'for research evidence about health systems. Health Res Policy Syst. 2015;13:10.

26. Dixon-Woods M, Cavers D, Agarwal S, Annandale E, Arthur A, Harvey J, et al. Conducting a critical interpretive synthesis of the literature on access to healthcare by vulnerable groups. BMC Med Res Methodol. 2006;6:35.

27. Covidence. About us Australia: Covidence; 2017. https://www.covidence org/about-us.

28. Hall PA. The role of interests, institutions, and ideas in the comparative political economy of the industrialized nations. In: Comparative politics: rationality, culture, and structure. Cambridge: Cambridge University Press; 1997. p. 174-207.

29. Oliver MJ, Pemberton $\mathrm{H}$. Learning and change in 20th-century British economic policy. Governance. 2004;17(3):415-41.

30. Walsh Jl. When do ideas matter? Explaining the successes and failures of Thatcherite ideas. Comp Political Stud. 2000;33(4):483-516.

31. QSR International. NVivo for Mac Australia: QSR International; 2017. http:// www.qsrinternational.com/product/nvivo-mac.

32. Charmaz K. Constructing grounded theory. London: Sage; 2014.

33. Glaser BG, Strauss A. The discovery of ground theory. Chicago: Aldine; 1967.

34. Van Wagner V, Epoo B, Nastapoka J, Harney E. Reclaiming birth, health, and community: Midwifery in the Inuit villages of Nunavik, Canada. J Midwifery Womens Health. 2007;52(4):384-91.

35. Epoo B, Stonier J, Wagner W, Harney E. Learning midwifery in Nunavik: community-based education for Inuit midwives. J Indigenous Wellbeing 2012;10(3):283-99.

36. Wagner V, Osepchook C, Harney E, Crosbie C, Tulugak M. Remote midwifery in Nunavik, Quebec, Canada: outcomes of perinatal care for the Inuulitsivik Health Centre, 2000-2007. Birth Issue Perinat Care. 2012;39(3):230-7.

37. Wrede $S$, Benoit $C$, Einarsdottir T. Equity and dignity in maternity care provision in Canada, Finland and Iceland. Can J Public Health. 2008;99:S16-21.

38. DeMaria LM, Campero L, Vidler M, Walker D. Non-physician providers of obstetric care in Mexico: perspectives of physicians, obstetric nurses and professional midwives. Hum Resour Health. 2012;10:6

39. Van Lerberghe W, Matthews Z, Achadi E, Ancona C, Campbell J, Channon A, et al. Country experience with strengthening of health systems and deployment of midwives in countries with high maternal mortality. Lancet. 2014;384(9949):1215-25.
40. Bogren M, Erlandsson K. Opportunities, challenges and strategies when building a midwifery profession. Findings from a qualitative study in Bangladesh and Nepal. Sex Reprod Healthc. 2018;16:45-9.

41. Temmar F, Vissandjee B, Hatem M, Apale A, Kobluk D. Midwives in Morocco: seeking recognition as skilled partners in women-centred maternity care. Reprod Health Matters. 2006;14(27):83-90.

42. Betron ML, McClair TL, Currie S, Banerjee J. Expanding the agenda for addressing mistreatment in maternity care: a mapping review and gender analysis. Reprod Health. 2018;15(1):143.

43. Filby A, McConville F, Portela A. What prevents quality midwifery care? A systematic mapping of barriers in low and middle income countries from the provider perspective. PLoS One. 2016;11(5):e0153391.

44. Witter S, Namakula J, Wurie H, Chirwa Y, So S, Vong S, et al. The gendered health workforce: mixed methods analysis from four fragile and postconflict contexts. Health Policy Plann. 2017:32(Suppl. 5):v52-62.

45. Turkmani S, Currie S, Mungia J, Assefi N, Rahmanzai AJ, Azfar P, et al. 'Midwives are the backbone of our health system': lessons from Afghanistan to guide expansion of midwifery in challenging settings. Midwifery. 2013; 29(10):1166-72.

46. Beek K, McFadden A, Dawson A. The role and scope of practice of midwives in humanitarian settings: a systematic review and content analysis. Hum Resour Health. 2019;17:5.

47. Devane D, Murphy-Lawless J, Begley CM. Childbirth policies and practices in Ireland and the journey towards midwifery-led care. Midwifery. 2007;23(1): 92-101.

48. Brodie P. Addressing the barriers to midwifery--Australian midwives speaking out. Aust J Midwifery. 2002;15(3):5-14.

49. Christiaens W, Nieuwenhuijze MJ, de Vries R. Trends in the medicalisation of childbirth in Flanders and the Netherlands. Midwifery. 2013;29(1):e1-8.

50. Goodman S. Piercing the veil: the marginalization of midwives in the United States. Soc Sci Med. 2007;65(3):610-21.

51. Kennedy HP, Rousseau AL, Low LK. An exploratory metasynthesis of midwifery practice in the United States. Midwifery. 2003;19(3):203-14.

52. Mattison CA, Lavis JN, Hutton EK, Dion ML, Wilson MG. Understanding the conditions that influence the roles of midwives in Ontario, Canada's health system: an embedded single-case study. BMC Health Serv Res. 2020;20(1):197.

53. Barger MK, Hackley B, Bharj KK, Luyben A, Thompson JB. Knowledge and use of the ICM global standards for midwifery education. Midwifery. 2019; 79:102534.

54. James S, O'Brien B, Bourret K, Kango N, Gafvels K, Paradis-Pastori J. Meeting the needs of Nunavut families: a community-based midwifery education program. Circumpolar special issue: human health at the ends of the earth. Rural Remote Health. 2010;10(2):1355.

55. Kildea S, Kruske S, Barclay L, Tracy S. 'Closing the gap': how maternity services can contribute to reducing poor maternal infant health outcomes for Aboriginal and Torres Strait Islander women. Rural Remote Health. 2010;10(3):1383.

56. Kreiner M. Delivering diversity: newly regulated midwifery returns to Manitoba, Canada, one community at a time. J Midwifery Women Health. 2009:54(1):e1-e10.

57. National Aboriginal Health Organization. Midwifery and aboriginal midwifery in Canada. Ottawa: National Aboriginal Health Organization; 2004.

58. Skye AD. Aboriginal midwifery: a model for change. Int J Indigenous Health. 2010;6(1):28-37.

59. Mavalankar D, Raman PS, Vora K. Midwives of India: missing in action. Midwifery. 2011:27(5):700-6.

60. Munabi-Babigumira S, Nabudere H, Asiimwe D, Fretheim A, Sandberg K. Implementing the skilled birth attendance strategy in Uganda: a policy analysis. BMC Health Serv Res. 2019;19:655.

61. Day-Stirk F, Fauveau V. The state of the world's midwifery: making the invisible visible. Int J Gynecol Obstet. 2012;119:S39-41.

62. Hogberg $U$. The decline in maternal mortality in Sweden: the role of community midwifery. Am J Public Health. 2004;94(8):1312-20.

63. ten Hoope-Bender P, Lopes STC, Nove A, Michel-Schuldt M, Moyo NT, Bokosi M, et al. Midwifery 2030: a woman's pathway to health. What does this mean? Midwifery. 2016;32:1-6.

64. Shakibazadeh E, Namadian M, Bohren MA, Vogel JP, Rashidian A, Pileggi VN, et al. Respectful care during childbirth in health facilities globally: a qualitative evidence synthesis. BJOG. 2018:125(8):932-42.

65. Oliver K, Parolin Z. Assessing the policy and practice impact of an international policy initiative: the state of the world's midwifery 2014. BMC Health Serv Res. 2018;18(1):499. 
66. World Health Organization. Nursing and Midwifery in the history of the World Health Organization 1948-2017. Geneva: WHO; 2017.

67. Spies LA, Garner SL, Faucher MA, Hastings-Tolsma M, Riley C, Millenbruch J, et al. A model for upscaling global partnerships and building nurse and midwifery capacity. Int Nurs Rev. 2017;64(3):331-44.

68. Chamberlain J, McDonagh R, Lalonde A, Arulkumaran S. The role of professional associations in reducing maternal mortality worldwide. Int J Gynecol Obstet. 2003;83(1):94-102.

69. Haththotuwa R, Senanayake L, Senarath U, Attygalle D. Models of care that have reduced maternal mortality and morbidity in Sri Lanka. Int I Gynaecol Obstet. 2012;119(Suppl 1):S45-9.

70. de Bernis L. Implementation of midwifery school accreditation mechanisms in Ivory Coast, Mali and Chad. Sante Publique. 2018;30:57-63.

71. Homer CSE, Castro Lopes S, Nove A, Michel-Schuldt M, McConville F, Moyo NT, et al. Barriers to and strategies for addressing the availability, accessibility, acceptability and quality of the sexual, reproductive, maternal, newborn and adolescent health workforce: addressing the post-2015 agenda. BMC Pregnancy Childbirth. 2018;18(1):55.

72. Nabirye RC, Kinengyere AA, Edwards G. Nursing and midwifery research output in Africa: a review of the literature. Int J Childbirth. 2018;8(4):236-41.

73. Koblinsky M, Matthews Z, Hussein J, Mavalankar D, Mridha MK, Anwar I, et al. Going to scale with professional skilled care... third in a series of five articles. Lancet. 2006;368(9544):1377-86.

74. World Health Organization. Munich declaration - nurses and midwives: a force for health. Intensive Crit Care Nurs. 2000;16(4):207-8.

75. Vedam S, Stoll K, MacDorman M, Declercq E, Cramer R, Cheyney M, et al. Mapping integration of midwives across the United States: impact on access, equity, and outcomes. PLoS One. 2018;13(2):e0192523.

76. Downe S, Finlayson K, Fleming A. Creating a collaborative culture in maternity care. J Midwifery Womens Health. 2010;55(3):250-4.

77. College of Midwives of Ontario. The Midwifery Scope of Practice: The College of Midwives of Ontario Submission to the Health Professions Regulatory Advisory Council. Toronto: College of Midwives of Ontario; 2008.

78. Hoope-Bender P, Renfrew MJ. Midwifery - a vital path to quality maternal and newborn care: the story of the Lancet series on midwifery. Midwifery. 2014;30(11):1105-6.

79. Scholmerich VL, Posthumus AG, Ghorashi H, Waelput AJ, Groenewegen P, Denktas S. Improving interprofessional coordination in Dutch midwifery and obstetrics: a qualitative study. BMC Pregnancy Childbirth. 2014;14:145.

80. Peterson C. Midwifery and the crowning of health care reform. J Midwifery Womens Health. 2010;55(1):5-8.

81. Bogren MU, Berg M, Edgren L, Ev T, Wigert H. Shaping the midwifery profession in Nepal - uncovering actors' connections using a Complex Adaptive Systems framework. Sex Reprod Healthc. 2016;10:48-55.

82. Bogren MU, van Teijlingen E, Berg M. Where midwives are not yet recognised: a feasibility study of professional midwives in Nepal. Midwifery. 2013;29(10):1103-9.

83. Klopper HC, Madigan E, Vlasich C, Albien A, Ricciardi R, Catrambone C, et al. Advancement of global health: recommendations from the Global Advisory Panel on the Future of Nursing \& Midwifery (GAPFON (R)). J Adv Nurs. 2020; 76(2):741-8

84. Binfa L, Pantoja L, Ortiz J, Gurovich M, Cavada G. Assessment of the implementation of the model of integrated and humanised midwifery health services in Santiago, Chile. Midwifery. 2013;29(10):1151-7.

85. Bergevin $Y$, Fauveau $V$, McKinnon B. Towards ending preventable maternal deaths by 2035. Semin Reprod Med. 2015;33(1):23-9.

86. Donnay F. Maternal survival in developing countries: what has been done, what can be achieved in the next decade. Int J Gynecol Obstet. 2000;70(1): 89-97.

87. Castro Lopes S, Nove A, Hoope-Bender P, Bernis LD, Bokosi M, Moyo NT, et al. A descriptive analysis of midwifery education, regulation and association in 73 countries: the baseline for a post-2015 pathway. Hum Resour Health. 2016:14:37.

88. Bvumbwe T, Mtshali N. Nursing education challenges and solutions in Sub Saharan Africa: an integrative review. BMC Nurs. 2018;17:3.

89. Yalahow A, Hassan M, Foster AM. Training reproductive health professionals in a post-conflict environment: exploring medical, nursing, and midwifery education in Mogadishu, Somaila. Reprod Health Matters. 2017;25(51):114-23.

90. Ajuebor O, McCarthy C, Li Y, Al-Blooshi SM, Makhanya N, Cometto G. Are the global strategic directions for strengthening nursing and midwifery
2016-2020 being implemented in countries? Findings from a crosssectional analysis. Hum Resour Health. 2019;17:54.

91. Nagle C, McDonald S, Morrow J, Kruger G, Cramer R, Couch S, et al. Informing the development midwifery standards for practice: a literature review for policy development. Midwifery. 2019;76:8-20.

92. Sandwell R, Bonser D, Hebert E, Kilroy K, Leshabari S, Mwanga F, et al. Stronger together: midwifery twinning between Tanzania and Canada. Glob Health. 2018;14(1):123.

93. West F, Homer C, Dawson A. Building midwifery educator capacity in teaching in low and lower-middle income countries. A review of the literature. Midwifery. 2016;33:12-23.

94. Colvin CJ, de Heer J, Winterton L, Mellenkamp M, Glenton C, Noyes J, et al. A systematic review of qualitative evidence on barriers and facilitators to the implementation of task-shifting in midwifery services. Midwifery. 2013; 29(10):1211-21.

95. Sidebotham M, Fenwick J, Rath S, Gamble J. Midwives' perceptions of their role within the context of maternity service reform: an appreciative inquiry. Women Birth. 2015;28(2):112-20.

96. McCarthy CF, Voss J, Verani AR, Vidot P, Salmon ME, Riley PL. Nursing and midwifery regulation and HIV scale-up: Establishing a baseline in East, Central and Southern Africa. J Int AIDS Soc. 2013;16:18051.

97. Jenkins GL. Burning bridges: policy, practice, and the destruction of midwifery in rural Costa Rica. Soc Sci Med. 2003;56(9):1893-909.

98. Fullerton J, Severino R, Brogan K, Thompson J. The International Confederation of Midwives' study of essential competencies of midwifery practice. Midwifery. 2003;19(3):174-90

99. Amelink-Verburg MP, Buitendijk SE. Pregnancy and labour in the Dutch maternity care system: what is normal? The role division between midwives and obstetricians. J Midwifery Women Health. 2010;55(3):216-25.

100. Homer CSE, Passant L, Brodie PM, Kildea S, Leap N, Pincombe J, et al. The role of the midwife in Australia: views of women and midwives. Midwifery. 2009;25(6):673-81.

101. Spendlove Z. Risk and boundary work in contemporary maternity care: tensions and consequences. Health Risk Soc. 2018;20(1-2):63-80.

102. Summer A, Walker D, Guendelman S. A review of the forces influencing maternal health policies in post-war Guatemala. World Med Health Policy. 2019;11(1):59-82.

103. Summer A, Walker $D$. Recommendations for sustainable midwifery in Guatemala. World Med Health Policy. 2018;10(4):356-80.

104. Kopacz L, Pawelec M, Pietras J, Karmowski A, Palczynski B, Karmowski M, et al. The Polish way to better midwifery or commercialization of maternity services? Adv Clin Exp Med. 2011;20(4):513-20.

105. Biro MA. What has public health got to do with midwifery? Midwives' role in securing better health outcomes for mothers and babies. Women Birth. 2011;24(1):17-23.

106. Homer CSE, Passant L, Kildea S, Pincombe J, Thorogood C, Leap N, et al. The development of national competency standards for the midwife in Australia. Midwifery. 2007;23(4):350-60.

107. Luyben A, Barger M, Avery M, Bharj KK, O'Connell R, Fleming V, et al. Exploring global recognition of quality midwifery education: vision or fiction? Women Birth. 2017;30(3):184-92.

108. Zhu X, Yao JS, Lu JY, Pang RY, Lu H. Midwifery policy in contemporary and modern China: from the past to the future. Midwifery. 2018;66:97-102.

109. McNeill J, Lynn F, Alderdice F. Public health interventions in midwifery: a systematic review of systematic reviews. BMC Public Health. 2012;12:955.

110. Mainey L, O'Mullan C, Reid-Searl K, Taylor A, Baird K. The role of nurses and midwives in the provision of abortion care: a scoping review. J Clinical Nurs. 2020;29(9-10):1513-26.

111. Fullerton J, Butler MM, Aman C, Reid T, Dowler M. Abortion-related care and the role of the midwife: a global perspective. Int J Womens Health. 2018;10: 751-62.

112. Massot E, Epaulard O. Midwives' perceptions of vaccines and their role as vaccinators: the emergence of a new immunization corps. Vaccine. 2018; 36(34):5204-9.

113. Van Hoover C, Holt L. Midwifing the end of life: expanding the scope of modern midwifery practice to reclaim palliative care. J Midwifery Women Health. 2016;61(3):306-14.

114. Alayande A, Mamman-Daura F, Adedeji O, Muhammad AZ. Midwives as drivers of reproductive health commodity security in Kaduna State, Nigeria. Eur J Contracept Reprod Health Care. 2016;21(3):207-12. 
115. Ir P, Korachais C, Chheng K, Horemans D, Van Damme W, Meessen B. Boosting facility deliveries with results-based financing: a mixed-methods evaluation of the government midwifery incentive scheme in Cambodia. BMC Pregnancy Childbirth. 2015:15:170.

116. King TL, Laros RK, Parer JT. Interprofessional collaborative practice in obstetrics and midwifery. Obstet Gynecol Clin North Am. 2012;39(3):411-22.

117. Arias MG, Nove A, Michel-Schuldt M, Bernis L. Current and future availability of and need for human resources for sexual, reproductive, maternal and newborn health in 41 countries in Sub-Saharan Africa. Int J Equity Health. 2017;16(1):69.

118. Suleiman-Martos N, Albendin-Garcia L, Gomez-Urquiza JL, Vargas-Roman K, Ramirez-Baena L, Ortega-Campos E, et al. Prevalence and predictors of burnout in midwives: a systematic review and meta-analysis. Int J Environ Res Public Health. 2020;17(2):641.

119. Nove A. The quality of midwifery education in six French-speaking subSaharan African countries. Sante Publique. 2018;30:45-55.

120. Renner RM, Brahmi D, Kapp N. Who can provide effective and safe termination of pregnancy care? A systematic review. BJOG. 2013;120(1):23-31.

121. Miyake S, Speakman EM, Currie S, Howard N. Community midwifery initiatives in fragile and conflict-affected countries: a scoping review of approaches from recruitment to retention. Health Policy Plan. 2017;32(1):21-33.

122. Sami S, Amsalu R, Dimiti A, Jackson D, Kenyi S, Meyers J, et al,

Understanding health systems to improve community and facility level newborn care among displaced populations in South Sudan: a mixed methods case study. BMC Pregnancy Childbirth. 2018;18(1):325.

\section{Publisher's Note}

Springer Nature remains neutral with regard to jurisdictional claims in published maps and institutional affiliations.

Ready to submit your research? Choose BMC and benefit from:

- fast, convenient online submission

- thorough peer review by experienced researchers in your field

- rapid publication on acceptance

- support for research data, including large and complex data types

- gold Open Access which fosters wider collaboration and increased citations

- maximum visibility for your research: over $100 \mathrm{M}$ website views per year

At BMC, research is always in progress.

Learn more biomedcentral.com/submissions 